\title{
Parasite loads and altitudinal distribution of Liolaemus lizards in the central Chilean Andes
}

\author{
Cargas parasitarias y distribución de lagartijas Liolaemus en los Andes de Chile \\ central
}

\begin{abstract}
JOHN H. CAROTHERS ${ }^{1} \&$ FABIÁN M. JAKSIC ${ }^{2}$
${ }^{1}$ Department of Zoology and Museum of Vertebrate Zoology, University of California, Berkeley, California 94720, U.S.A. Current address: Department of Biology, Cabrillo College, Aptos, California 95003, U.S.A., e-mail: jocaroth@cruzio.com

${ }^{2}$ Departamento de Ecología, Pontificia Universidad Católica de Chile, Casilla 114-D, Santiago, Chile, e-mail: fjaksic@genes.bio.puc.cl
\end{abstract}

\begin{abstract}
This study compared the distributions of ten species of Liolaemus lizards in the central Chilean Andes to the distributions of four types of parasites: malaria-causing Plasmodium, gut nematodes, ticks, and mites. We wanted to see if parasite numbers might be a factor in determining distributional limits of the lizards. We found that there was no evidence of malarial infestation of the lizards, that ticks were almost absent, that more often than not mite numbers decreased at the distributional limits of the lizards, and that gut nematodes — confined to the herbivorous lizards in our sample - may well be beneficial rather than detrimental. Rather than parasitism, other biotic interactions (e.g., predation or competition) are more likely candidates as factors influencing lizard elevational distributions, as are abiotic characteristics such as microhabitat availabilities and thermal factors.
\end{abstract}

Key words: malaria, Plasmodium, gut nematodes, ticks, mites, Chile, altitudinal gradient.

\section{RESUMEN}

Este estudio compara las distribuciones de diez especies de lagartijas Liolaemus en los Andes de Chile central, con las distribuciones de cuatro tipos de parásitos: Plasmodium causantes de malaria, nemátodos intestinales, garrapatas y ácaros. Quisimos verificar si los números de parásitos pudieran ser un factor determinante de los límites de distribución de las lagartijas. Encontramos que no había evidencia de infestación por malaria en las lagartijas; que las garrapatas estaban casi ausentes; que los números de ácaros más a menudo decrecían que aumentaban en los límites distribucionales de las lagartijas; y que los nemátodos intestinales — confinados a las lagartijas herbívoras en nuestra muestra— bien podían ser beneficiosos antes que dañinos. Más bien que parasitismo, otras interacciones bióticas (e.g., depredación o competencia) son candidatos más probables como factores que influyen las distribuciones altitudinales de las lagartijas, además de características abióticas tales como la disponibilidad de microhábitats y los factores térmicos.

Palabras clave: malaria, Plasmodium, nemátodos intestinales, garrapatas, ácaros, Chile, gradiente altitudinal.

\section{INTRODUCTION}

We examine altitudinal distributions of lizards of the South American Andean tropidurid genus Liolaemus, with regard to their respective parasite loads. Lizards can be infested with a variety of parasites: those most commonly studied are ticks, mites, and malarial plasmodia. The latter occur in a variety of lizard species (Bonorris \& Ball 1955, Ayala 1970, 1977, 1978, Telford 1970, 1971, 1972, 1977, 1978, Jordan \& Friend 1971, Guerrero et al. 1977) and have been shown to have an important impact upon the biology of some lizards (Scorza 1971, Schall et al. 1982, Schall 1983). Studies on some ectoparasites have demonstrated their effect on vertebrates other than lizards (e.g., Smith 1968, Warner 1968, Arendt 1985a, 1985b).

The purpose of this study is to compare the distributions of species of lizards to those of their parasites along a steep altitudinal gradient, to evaluate if parasites may be a factor in determining Liolaemus distributional limits (Carothers et al. 1996, see also Dobson \& Hudson 1986). 


\section{MATERIAL AND METHODS}

\section{Field locations and time of study}

This study was conducted in the Andean Cordillera near Santiago, Chile, from October through December of both 1984 and 1985. These times covered the Southern Hemisphere's spring and early summer months, during the period of peak activity by lizards. During these two field seasons altitudinal distributions and abundances of lizards were mapped along three transects from 1,500 up to 3,000 $\mathrm{m}$ elevation in Farellones, Lagunillas, and El Volcán. Each transect was within $40 \mathrm{~km}$ of a neighboring transect, so that latitudinal effects of climate variation were minimized. In general, the habitats at lower elevations consisted of mediterranean-type scrub («matorral») and scattered rocks and trees, shifting gradually to low-growing bushes, and more numerous rocks and boulders at high elevations. During the first year of the study, blood smears for detecting malarial infestations were taken from captured lizards when they were being marked by toe clipping for recapture the following year. During both years lizards were inspected for ectoparasites. Preserved specimens collected in all years were examined for nematodes in their gut.

\section{Blood protozoan analysis}

Methods follow those of Ayala \& Spain (1976) for malarial plasmodia and other parasitic blood protozoans. Lizards were toe-clipped, and a small drop of blood was squeezed out of the toe onto a glass slide. Another glass slide was then brought up until it just touched to blood drop so that it spread along the edge of the second slide, which was then quickly slid away. This method provided a good blood smear without rupturing any of the red blood cells. The smears were labeled with the number of the lizard from which the sample was taken so that species and elevation could later be determined, after which the smear was fixed in absolute methanol. The slides were later stained with Giemsa solution, and examined under a microscope for the presence of malarial plasmodia in the nuclei of the red blood cells.

\section{Acarine analyses}

For each of the captured and released lizards, counts were made of the numbers of ticks and mites with which they were infested. Because ticks are relatively large in size and generally not numerous, their numbers were easily counted and recorded. In contrast, mites sometimes were present in numbers greater than 100. Because of their being so numerous and of their small size, mite numbers were approximated by counting in groups of five in order to speed handling time. The species identities of the acarine ectoparasites were not determined.

\section{Ectoparasite frequencies}

Two indices of ectoparasite frequencies were used in the following analyses: (a) direct count of the number of ectoparasites present on a lizard, (b) degree of infestation by an ectoparasite, that is, the number of ectoparasites found on an individual lizard divided by the body length (measured as snout to vent length) of that lizard. This distinction was made because the lizard species studied differ markedly in body size. If the putative effect of ectoparasites is proportional to their combined numbers relative to the size of an infested lizard, this latter statistic is a more appropriate measure of parasite impact. If possible effects are more the result of ectoparasite numbers than of ectoparasites present, then the former measure is more relevant. Neither possibility could be deemed more relevant in advance.

\section{Nematode analyses}

Some lizard specimens were collected in order to examine them for the presence of possible gut parasites. Those individuals were killed with an overdose of Nembutal, fixed in $10 \%$ formalin, and stored in $70 \%$ ethanol. Their gut was then removed and the contents were examined under a dissecting scope.

\section{RESULTS}

\section{Parasitic blood protozoan abundances and distributions}

Although more than 300 blood smears were examined for the presence of reptilian blood protozoans, none showed any evidence of infestation: trophozoite, sporozoite, schizont, merozoite, and gametocyte stages were absent. As a consequence, no relation could be examined between distributions of lizard species and blood protozoans in these lizards at the three study areas. Lizard malaria has yet to be detected in members of the genus Liolaemus (S.C. Ayala, 
personal communication), and when malaria in lizards is present it usually occurs below the lower elevational limit of the transects in this study (S.C. Ayala, personal communication).

\section{Tick abundances and distributions}

Ticks were observed in very low numbers on the lizards captured in this study. Five of the ten Liolaemus species showed no evidence of tick infestation, and ticks were usually absent from most individuals of the other five species as well (Table 1). Contingency table analysis (eliminating the five species that lacked ticks) revealed that significant differences existed in the number of individuals of each lizard species infested with ticks as compared to those without ticks (G-test, $\mathrm{G}=27.16$, d.f. $=4, \mathrm{P}<0.001)$. There were also significant differences in mean number of ticks carried by each species (analysis of variance, $\left.\mathrm{F}_{1,1733}=4.76, \mathrm{P}<0.05\right)$. Differences also existed in the mean degree of tick infestation in each species (analysis of variance, $\mathrm{F}_{1,1733}=5.13, \mathrm{P}<$ $0.05)$.

Both the number of ticks on lizards and the degree of tick infestation increased with elevation (analysis of variance, $\mathrm{F}_{1,1733}=8.93, \mathrm{P}<0.01$, and $\mathrm{F}_{1,1733}=6.89, \mathrm{P}<0.01$, respectively). However, this result was obtained by pooling tick numbers among all Liolaemus species: when these tick data were studied by host lizard species there were too few data for statistical analysis. Thus, it is not possible to determine if the elevational trend results simply from a differential preference by ticks for high-elevation lizard species or from a true elevational effect.

\section{Mite abundances and distributions}

Mites on captured lizards appeared in much greater abundances than did ticks, and all but Liolaemus schroederi carried mites (the small sample size of this species, $\mathrm{n}=16$, probably explains the lack of evidence of mite infestation). There were significant differences in mean number of mites that each lizard species carried (analysis of variance, $\left.\mathrm{F}_{1.1733}=5.61, \mathrm{P}<0.05\right)$. However, measures of the mean degree of mite infestation in each lizard species (correcting for size differences among the lizard species) revealed no differences (analysis of variance, $\mathrm{F}_{1,1733}=1.61, \mathrm{P}$ $>0.20$ ). Contingency table analysis revealed significant differences in the number of individuals of each lizard species infested with mites as compared to those without mites (G-test, $\mathrm{G}=91.35$, d.f. $=9, \mathrm{P}<0.001)$.

Because mites were in much greater numbers than were ticks, sufficient sample sizes were present for analyses of their elevational distributions among the study sites on the three

TABLE 1

Tick abundance among ten Liolaemus species. Letters denote species as follows: alti $=L$. altissimus, chil $=$ L. chiliensis, fusc $=$ L. fuscus, lemn $=$ L. lemniscatus, leop $=$ L. leopardinus, mont $=$ L. monticola, nigr $=$ L. nigroviridis, niti $=$ L. nitidus, $\mathrm{schr}=$ L. schroederi, tenu $=L$. tenuis

Abundancia de garrapatas entre diez especies de Liolaemus. Las letras denotan especies según se especifica arriba

\begin{tabular}{|c|c|c|c|c|c|c|c|c|c|c|}
\hline & \multicolumn{10}{|c|}{ Liolaemus species } \\
\hline & alti & chil & fusc & lemn & leop & mont & nigr & niti & $\operatorname{schr}$ & tenu \\
\hline Sample size & 258 & 8 & 114 & 365 & 108 & 277 & 374 & 176 & 12 & 51 \\
\hline Number of lizards with ticks & 0 & 0 & 0 & 1 & 10 & 6 & 9 & 1 & 0 & 0 \\
\hline Lizards with ticks (\%) & 0 & 0 & 0 & 0.2 & 9.3 & 2.2 & 2.4 & 0.6 & 0 & 0 \\
\hline \multicolumn{11}{|l|}{ Tick numbers: } \\
\hline Maximum & 0 & 0 & 0 & 1 & 11 & 6 & 3 & 1 & 0 & 0 \\
\hline$\overline{\mathrm{x}}$ & 0 & 0 & 0 & $<0.01$ & 0.30 & 0.06 & 0.04 & $<0.01$ & 0 & 0 \\
\hline SD & - & - & - & 0.05 & 1.31 & 0.49 & 0.31 & 0.08 & - & - \\
\hline \multicolumn{11}{|l|}{ Degree of tick infestation: } \\
\hline Maximum & 0 & 0 & 0 & 0.26 & 0.73 & 0.67 & 0.36 & 0.06 & 0 & 0 \\
\hline$\overline{\mathrm{x}}$ & 0 & 0 & 0 & $<0.01$ & 0.03 & $<0.01$ & $<0.01$ & $<0.01$ & 0 & 0 \\
\hline SD & - & - & - & 0.01 & 0.12 & 0.05 & 0.03 & $<0.01$ & - & - \\
\hline
\end{tabular}




\section{TABLE 2}

Mite abundance among ten Liolaemus species. Letters denote species as follows: alti $=L$. altissimus, chil $=$ L. chiliensis, fusc $=$ L. fuscus, lemn $=$ L. lemniscatus, leop $=$ L. leopardinus, mont $=$ L. monticola, nigr $=$ L. nigroviridis, niti $=$ L. nitidus, $\mathrm{schr}=$ L. schroederi, tenu $=L$. tenuis

Abundancias de ácaros entre diez especies de Liolaemus. Las letras denotan especies según se especifica arriba

\begin{tabular}{lcccccccccc}
\hline & & \multicolumn{7}{c}{ Liolaemus species } & & \\
& alti & chil & fusc & lemn & leop & mont & nigr & niti & schr & tenu \\
\hline Sample size & 258 & 8 & 114 & 365 & 108 & 277 & 374 & 176 & 12 & 51 \\
Number of lizards with mites & 39 & 1 & 84 & 240 & 50 & 202 & 233 & 86 & 0 & 24 \\
Lizards with mites (\%) & 54 & 13 & 74 & 66 & 46 & 73 & 62 & 49 & 0 & 49 \\
Mite numbers: & & & & & & & & & & \\
Maximum & 100 & 5 & 70 & 90 & 180 & 200 & 150 & 180 & 0 & 50 \\
$\overline{\mathrm{x}}$ & 10.98 & 0.63 & 15.16 & 11.26 & 13.30 & 21.21 & 16.74 & 13.30 & 0 & 6.12 \\
SD & 17.41 & 1.77 & 14.47 & 14.57 & 30.08 & 25.68 & 23.76 & 30.08 & - & 11.03 \\
Degree of mite infestation: & & & & & & & & & & \\
Maximum. & 19.23 & 1.28 & 22.73 & 33.33 & 11.25 & 36.00 & 38.89 & 11.36 & 0 & 11.11 \\
$\overline{\mathrm{x}}$ & 1.68 & 0.16 & 5.03 & 3.89 & 0.89 & 4.52 & 2.91 & 0.79 & 0 & 1.26 \\
SD & 3.05 & 0.45 & 5.10 & 5.46 & 1.92 & 5.85 & 5.02 & 1.68 & - & 2.48 \\
\hline
\end{tabular}

transects. With no differences occurring among species in degree of mite infestation, these data were pooled and regressed against elevation. A slightly negative $(r=-0.20)$ elevational effect on degree of mite infestation indeed occurs (analysis of variance, $\left.\mathrm{F}_{1,1733}=73.43, \mathrm{P}<0.001\right) . \mathrm{A} \mathrm{X}^{2}$ comparison of degree of mite infestation at maximum and minimum elevations for species within a given transect that span a distribution of at least $300 \mathrm{~m}$ showed a decrease with elevation in nine out of 12 cases (Chi-square test, $\mathrm{X}^{2}=3.0, \mathrm{P}$ $<0.09)$, an insignificant trend. In only five of these 12 cases did the degree of mite infestation increase at the distributional limits of the various Liolaemus species.

\section{Nematode occurrences}

Dissections revealed that nematodes occurred only in three species: L. altissimus, L. leopardinus, and L. nitidus.

\section{DISCUSSION}

In the only other study reporting elevational patterns of acarine infestation on lizards, Spoecker (1967) reported an increase with elevation of mites on the iguanid Uta stansburiana. He suggested that this pattern may be attributable to milder, moister conditions at the higher elevation site. The opposite elevational pattern occurred among the mites that infested Liolaemus.

Unfortunately, far more is known about the biology of reptile mites and ticks and of the effects of their reptilian hosts on their own biology (Norval 1975, Bull 1978, Andrews et al. 1982a, 1982b, Werman 1983) than is known about their effect upon their hosts, except that they sometimes serve as vectors for parasitic blood protozoans (Goodwin 1954, Lewis \& Wagner 1964). Several studies have reported that lizard host numbers greatly influence the densities and life histories of their acarine parasites (Norval 1975, Bull 1978, Wilson et al. 1985). Although a negative effect on lizards by these ectoparasites has sometimes been assumed (e.g., Arnold 1986), it has yet to be demonstrated. And their importance as a critical determinant of lizard distributions is unlikely. Despite the mild elevational trend in mite occurrence detected in this study, more often than not mite and tick abundances decreased at the distributional limits of their Liolaemus lizard hosts. Although saurian malaria has been demonstrated to have a measurable impact upon the life histories of lizards (Schall et al. 1982, Schall 1983), its absence from these populations of Liolaemus indicates that it plays no role in affecting their elevational distribution patterns. 
With regard to the presence of nematodes in three Liolaemus species, a common feature of the biologies of these lizards is quite relevant: all are herbivorous. Nematodes have been observed to occur in the gut of a number of other herbivorous lizards (Iverson 1982). In contrast to being strictly parasitic, Iverson (1982) has proposed that these intestinal occupants may actually aid in the breakdown of cellulose in the diet of herbivorous lizards. Thus, they may have a beneficial rather than harmful effect upon the lizards they inhabit. Further research on their life cycles and relationship with herbivorous lizards is clearly needed (e.g., Jaksic \& Fuentes 1980).

In conclusion, it is apparent that the parasitic and parasitic-type organisms do not play major roles in setting distributional limits for Liolaemus lizards in the central Chilean cordillera. Malarial plasmodia are absent, ticks are in too few numbers, mites are sometimes abundant but no strong elevational pattern exists (and a truly negative effect by them has yet to be demonstrated for any lizard species), and gut nematodes, confined to the herbivorous lizards in our sample, may well be beneficial rather than detrimental. It is entirely possible that extreme outbreaks of parasites occurring in a periodic manner could have an impact upon the distributions of the lizards, but observations on the populations over a considerable time period would be required to determine this possibility. Rather than parasitism, other biotic interactions (e.g., predation or competition) are more likely candidates as factors influencing lizard elevational distributions, as are abiotic characteristics such as microhabitat availabilities and thermal factors (Carothers et al. 1996, 1997, 1998).

\section{ACKNOWLEDGMENTS}

Financial support came from a Kellogg Fund grant and an Annie Alexander Fellowship, both administered by the Museum of Vertebrate Zoology at University of California, Berkeley. Also, from the Tinker Fund of University of California Berkeley's Center for Latin American Studies and a National Science Foundation Doctoral Dissertation Improvement Grant. We thank Antonieta Labra, Larry Minden, Hilary Stoermer, and Steve Wong for field assistance. Comments by Harry Greene, Robert Robichaux, and David Wake are greatly appreciated. Two anonymous reviewers made valuable comments.

\section{LITERATURE CITED}

ANDREWS RH, TN PETNEY \& CM BULL (1982a) Reproductive interference between three parapatric species of reptile tick. Oecologia 52: 281-286.

ANDREWS RH, TN PETNEY \& CM BULL (1982b) Niche changes between parasite populations: an example from ticks on reptiles. Oecologia 55: 77-80.

ARENDT WJ (1985a) Philornis ectoparasitism of pearlyeyed thrashers. I. Impact on growth and development of nestlings. Auk 102: 270-280.

ARENDT WJ (1985b) Philornis ectoparasitism of pearlyeyed thrashers. II. Effects on adults and reproduction. Auk 102: 281-292.

ARNOLD EN (1986) Mite pockets of lizards, a possible means of reducing damage by ectoparasites. Biological Journal of the Linnean Society 29: 1-21.

AYALA SC (1970) Lizard malaria in California; description of a strain of Plasmodium mexicanum, and biogeography of lizard malaria in western North America. Journal of Parasitology 56: 417-425.

AYALA SC (1977) Plasmodia of reptiles. In: Kreier JP (ed) Parasitic protozoa. Volume 3: Gregarines, Haemogregines, Coccidia, Plasmodia, and Haemoproteids. Academic Press, New York, New York.

AYALA SC (1978) Checklist, host index, and annotated bibliography of Plasmodium from reptiles. Journal of Protozoology 25: 87-100.

AYALA SC \& JL SPAIN (1976) A population of Plasmodium colombiense sp. $\mathrm{n}$. in the iguanid lizard, Anolis auratus. Journal of Parasitology 62: 177-189.

BONORRIS JS \& GH BALL (1955) Schellackia occidentalis $\mathrm{n}$. sp., a blood-inhabiting coccidian found in lizards in southern California. Journal of Protozoology 2: 31-34.

BULL CM (1978) Dispersal of the Australian reptile tick Aponomma hydrosauri by host movement. Australian Journal of Zoology 26: 689-697.

CAROTHERS JH, FM JAKSIC \& PA MARQUET (1996) A model for species distributions along a gradient: lizards as study systems. Revista Chilena de Historia Natural 69: 301-307.

CAROTHERS JH, SF FOX, PA MARQUET \& FM JAKSIC (1997) Thermal characteristics of ten Andean lizards of the Chilean genus Liolaemus. Revista Chilena de Historia Natural 70: 297-309.

CAROTHERS JH, PA MARQUET \& FM JAKSIC (1998) Thermal ecology of a Liolaemus lizard assemblage along an Andean altitudinal gradient in Chile. Revista Chilena de Historia Natural 71: 39-50.

DOBSON AP \& PJ HUDSON (1986) Parasites, disease and the structure of ecological communities. Trends in Ecology and Evolution 1: 11-15.

GOODWIN MH (1954) Observations on the biology of the lizard mite Geckobiella texana (Banks) 1904 (Acarina: Pterygosomidae). Journal of Parasitology 40: 54-59.

GUERRERO S, C RODRÍGUEZ \& SC AYALA (1977) Prevalencia de hematoparasitos en lagartijas de la isla Barro Colorado, Panama. Biotropica 9: 118-123.

IVERSON JB (1982) Adaptations to herbivory in iguanine lizards. In: Burghardt GM \& AS Rand (eds) Iguanas of the world: their behavior, ecology and conservation: 60-76. Noyes Publishers, Park Ridge, New Jersey. 
JAKSIC FM \& ER FUENTES (1980) Observaciones autoecológicas en Liolaemus nitidus (Lacertilia: Iguanidae). Studies on Neotropical Fauna and Environment 15: 109-124.

JORDAN HB \& MB FRIEND (1971) The occurrence of Schellackia and Plasmodium in two Georgia lizards. Journal of Protozoology 18: 485-487.

LEWIS R \& ED WAGNER (1964) Hepatozoon sauromali sp. n., a hemogregarine from the chuckwalla (Sauromalus spp.) with notes on the life history. Journal of Parasitology 50: 111-122.

NORVAL RAI (1975) Studies on the ecology of Amblyomma marmoreum Koch 1844 (Acarina: Ixodidae). Journal of Parasitology 61: 737-742.

SCHALL JJ (1983) Lizard malaria: parasite-host ecology. In: Huey RB, ER Pianka \& TW Schoener (eds) Lizard ecology: studies of a model organism: 84-100. Harvard University Press, Cambridge, Massachusetts.

SCHALL JJ, AF BENNETT \& RW PUTMAN (1982) Lizards infected with malaria: physiological and behavioral consequences. Science 217: 1057-1059.

SCORZA JV (1971) Anaemia in lizard malaria infections. Parassitologia 13: 391-405.

SMITH NG (1968) The advantage of being parasitized. Nature 219: 690-694.

SPOECKER PD (1967) Ectoparasites of a Mojave desert population of the lizard Uta stansburiana stejnegeri Schmidt. American Midland Naturalist 77: 539-542.
TELFORD SR (1970) A comparative study of endoparasitism among some southern California lizard populations. American Midland Naturalist 83: 516554.

TELFORD SR (1971) Parasitic diseases of reptiles. Journal of the American Veterinary Medicine Association 159: 1644-1652.

TELFORD SR (1972) The course of infection of Japanese saurian malaria (Plasmodium sasai, Telford and Ball) in natural and experimental hosts. Japanese Journal of Experimental Medicine 42: 1-21.

TELFORD SR (1977) The distribution, incidence, and general ecology of saurian malaria in Middle America. International Journal of Parasitology 7: 299-314.

TELFORD SR (1978) The saurian malarias of Venezuela: haemosporidian parasites of gekkonid lizards. International Journal of Parasitology 8: 341-353.

WERMAN SD (1983) Population dynamics of the lizard mite, Hirstiella pyriformis (Acari: Pterygosomatidae) on the chuckwalla, Sauromalus obesus (Sauria: Iguanidae). Journal of Parasitology 69: 381-386.

WILSON ML, GH ADLER \& A SPIELMAN (1985) Correlation between abundance of deer and that of the deer tick, Ixodes dammini (Acari: Ixodidae). Annals of the Entomological Society of America 78: 172-176. 